\title{
Atualidade da crítica e da teoria das literaturas de expressão francesa
}

\begin{abstract}
"Dès l'instant où la subjectivité du critique se trouve prise en compte, celui-ci ne peut plus prétendre se limiter à la seule description ; il doit en même temps assumer ses jugements".

“Je n'ai donc pas plaidé pour une théorie parmi d'autres, ni pour le sens commun, mais pour la critique de toutes les théories, y compris celle du sens commun. La perplexité est la seule morale littéraire". ${ }^{2}$
\end{abstract}

Este dossiê reúne trabalhos de pesquisadores que fornecem um panorama da atualidade da crítica e da teoria das literaturas de expressão francesa. $\mathrm{O}$ resultado é uma seleta preciosa, que tanto retoma temáticas já consagradas nos estudos das literaturas francófonas quanto convida à descoberta de autores e problemáticas contemporâneas. Assim, partindo do Romantismo e da formação cenacular segundo a leitura de Pierre Bourdieu, no texto de Fernanda Almeida Lima, e passando pelo tópos da cena de baile no romance oitocentista, com o artigo de Cláudia Helena Daher, o dossiê atravessa os séculos XX e XXI, trazendo à cena desde a concepção de literatura de Maurice Blanchot, nas reflexões de Davi Andrade Pimentel, até o uso da metáfora

${ }^{1}$ TODOROV, Tzvetan. La littérature comme fait et valeur. In: Critique de la critique. Paris: Seuil, 1984. p. 174.

${ }^{2}$ COMPAGNON, Antoine. L'aventure théorique. In: . Le démon de la théorie. Paris: Seuil, 1998. p. 283. 
e da literalidade em Emmanuel Hocquard, em texto de Marília Garcia; das linhas de força da obra teórico-poética de Jean-Christophe Bailly, segundo Marcelo Jacques de Moraes, até as relações entre a poesia e a filosofia do teórico francês Michel Collot, no trabalho de Antônio Carlos Mousquer e Alberto Lopes de Mello, e a novíssima produção de JeanMarie Gleize e Christophe Hanna e suas Questions théoriques, em artigo de Masé Lemos. A atualidade da crítica transmuta-se, assim, também na atualidade da cena literária francesa contemporânea, demonstrando o vigor e uma certa perplexidade da produção, mas também da pesquisa nessa área. Pois de há dois séculos para cá não só a ficção se transforma, tornando-se difusa e metacrítica, mas também a própria poesia adquire novas figuras, tornando-se, como diz Denis Roche "inadmissível", ultrapassando as fronteiras do gênero e requerendo - para ser entendida - que se proceda a uma "pragmática erótica", uma busca do desejo e do sujeito sempre a desvanecer-se, como demonstra Stéphane Baquey.

Na seção "Varia", destacam-se análises comparatistas de objetos provenientes de áreas culturais bastante diversas, entre as quais as das literaturas francesa, russa, espanhola, latino-americana, brasileira e latina, sob enfoques originais e interdisciplinares. O primeiro artigo, de autoria de Bruno Fontes, apresenta uma análise de Le Mépris, de JeanLuc Godard, sob o ângulo do diálogo com a Odisseia, para questionar os limites da adaptação fílmica, bem como problematizar o diálogo entre a ausência e a presença da escrita no filme, escrita considerada em sua iconicidade e materialidade. Em seguida, a literatura russa é contemplada por Denise Regina Sales, que interroga de modo pertinente o importante papel da presença da estátua de Stálin no romance contemporâneo de Vladímir Voinovitch, Propaganda monumental. O terceiro artigo, de Elisa Amorim Vieira, propõe uma reflexão instigante sobre os fotorrelatos dos anos 1960, publicações que associam texto e imagem e cujo tema central é o cotidiano das cidades, a partir da hipótese de um ressurgimento do costumbrismo oitocentista. O ensaio de Lucas da Cunha Zamberlan, por sua vez, procura aproximar a potência imagética da narrativa PathéBaby, do escritor António de Alcântara Machado, do cinema e da pintura impressionista e de vanguarda. Para encerrar essa seção, apresentamos o artigo de Matheus Trevizam, de relevância para os estudos clássicos, que traz uma análise detalhada do emprego de imagens de caça na Ars 
amatoria, de Ovídio, poema didático vinculado sobretudo à apresentação de estratégias de conquista amorosa no ambiente urbano. Este volume da Aletria se encerra com a resenha de Lilian Pereira Nascimento e Marie-Hélène Catherine Torres da tradução do Conto do carpinteiro, livro infanto-juvenil escrito e ilustrado por Iban Barrenetxea.

Inês Oseki-Dépré

Maria Juliana Gambogi Teixeira 